\title{
The Impact of Anthropogenic Activities on Benthic Macroinvertebrates Community in the Ranggeh River
}

\author{
Jojok Sudarso', Tri Suryono', Gunawan P. Yoga', Octavianto Samir'1, \\ Imroatushshoolikhah', Aiman Ibrahim' \\ 1 Research Center for Limnology-LIPI, Jl. Jakarta Bogor Km 46 Cibinong, districts Bogor, 16911, West Java, \\ Indonesia \\ * Corresponding author's email: yoyo@limnologi.lipi.go.id
}

\begin{abstract}
Ranggeh River is one of the inlets of Lake Maninjau (West Sumatra, Indonesia), which has a vital role in supporting the life of native fish. Increasing anthropogenic activities (agriculture and human settlements) around the river can harm benthic macroinvertebrates as natural food for fish. Therefore, this study aimed to analyze and observe water quality changes and their impact on the benthic macroinvertebrate communities in the Ranggeh River. Sampling was conducted from February to August 2019 using the Hess Sampler tool. The results indicate that the anthropogenic impacts around the Ranggeh River on water quality has changed the macroinvertebrate benthic community structures (composition, abundance, and biological index). Furthermore, the Ephemeroptera Plecoptera and Trichoptera (EPT) number of taxa index were superior in reflecting disturbances in the Ranggeh River compared to the Family Biotic Index (FBI) and the Percent Model Affinity (PMA). In conclusion, the anthropogenic effect on the macroinvertebrate community in the Ranggeh River prominently was caused by habitat changes rather than enrichment by nutrients (TN and TP).
\end{abstract}

Keywords: EPT, pollution, agriculture, embeddedness percentage.

\section{INTRODUCTION}

River as a freshwater ecosystem has been prone to disturbance, due to some anthropogenic activities from its catchment area. The increase of anthropogenic activities such as agriculture, industries, and urban activities around the river has significantly affected the changes in water quality and quantity (Neissi et al., 2019). Some anthropogenic activities have been known to deteriorate the water quality of rivers including land clearing and land-use change, domestic waste discharge, industries, agriculture, and livestock (Patang et al., 2018). The decrease in water quality had caused changes in the benthic macroinvertebrate community structures (Kenney et al., 2009). As a consequence, the community structure had changed, for instance, taxa richness, biodiversity, dominance, and abundance of these organisms which reflect the level of disturbance in the river ecosystems (Xu et al., 2014). Thus, the degree of the change of community structure that relates to water quality status is crucial to reveal the impact of water quality changes on the macroinvertebrates community structures. Benthic macroinvertebrates have an essential role in many ecological processes on the transitional waters, rivers, and lakes. These animals can describe the changes of physical, chemical, and ecological habitat characteristics for periods of time continuously (Basset et al., 2004). Therefore, the community has been used effectively and cheaply to estimate water quality conditions including pollution, sedimentation (Maneechan \& Prommi, 2015), and evaluation of habitat rehabilitation (Besacier-Monbertrand et al., 2014; Miller et al., 2010). Several reasons for using benthic macroinvertebrates to assess water quality conditions is due to the wide range in distribution, high diversity in species, relatively sessile, various range 
tolerance on pollution degree, and their essential role in the food chain (Rosenberg \& Resh, 1993). Given the limitations of physical and chemical measurements that reflect momentary water conditions, combining it with biological parameters will be necessary to describe comprehensive water conditions (Lenat et al., 1980).

Ranggeh River is one of the inlets of Lake Maninjau, in West Sumatra, Indonesia. Its length is about $5.9 \mathrm{~km}$ and habitat for several native fishes for example Rasbora maninjau, Gobiopterus brachypterus, and Tor sp. Currently, the riparian in Ranggeh River is relatively open which suffers from disturbances due to land clearing activity for agricultural purposes, agricultural waste inputs, and the settlements. Furthermore, a lot of soil materials are eroded and settled on the riverbed, as the result of fine sediment will accumulate there and the habitat tends to be homogeneous in the rainy season. However, some efforts to protect Ranggeh River banks have been made, as an example, with gabion wires filled with stones (Sudarso et al.,2020).

The other problems in river ecosystems are nutrient enrichment and toxic pollutants from agricultural waste and settlements that affect benthic macroinvertebrates (Kenney et al., 2009). Agricultural activities have caused $70 \%$ of water pollution worldwide (Sagasta et al., 2017). Watts (2010) states that pesticides and fertilizers from agricultural activities have contributed to $43 \%$ of chemical oxygen demand, $67 \%$ of phosphorus, and $57 \%$ of nitrogen from waste heading to the river. These surely will lower the water quality, then it endangers benthic macroinvertebrates, in the terms of decreased biodiversity, changes the functional feeding, and leave only tolerant species (Duan et al., 2011). Therefore, this research wants to investigate the impact of agricultural activities and the settlements on the benthic macroinvertebrates community in the Ranggeh River. The objectives were to analyze and observe the change in water quality and its impact on the macroinvertebrate community in the Ranggeh River.

\section{MATERIALS AND METHODS}

\section{Study area}

This research was conducted from February to August 2019 in a section of Ranggeh River, West Sumatra. Four stations were established for observation which was purposely chosen based on pollutant input and anthropogenic activities around the river. The information of the characteristics of each location is illustrated in Table 1.

\section{Sampling and identification of benthic macroinvertebrates}

Macroinvertebrate samples were collected from February to August 2019 by using a Hess sampler (Diameter $30 \mathrm{~cm}$ ) with the filter pore of $0.5 \mathrm{~mm}$. The riffle sections were chosen because of its sensitivity to disturbances and typically inhabit by the most distinct communities of benthic

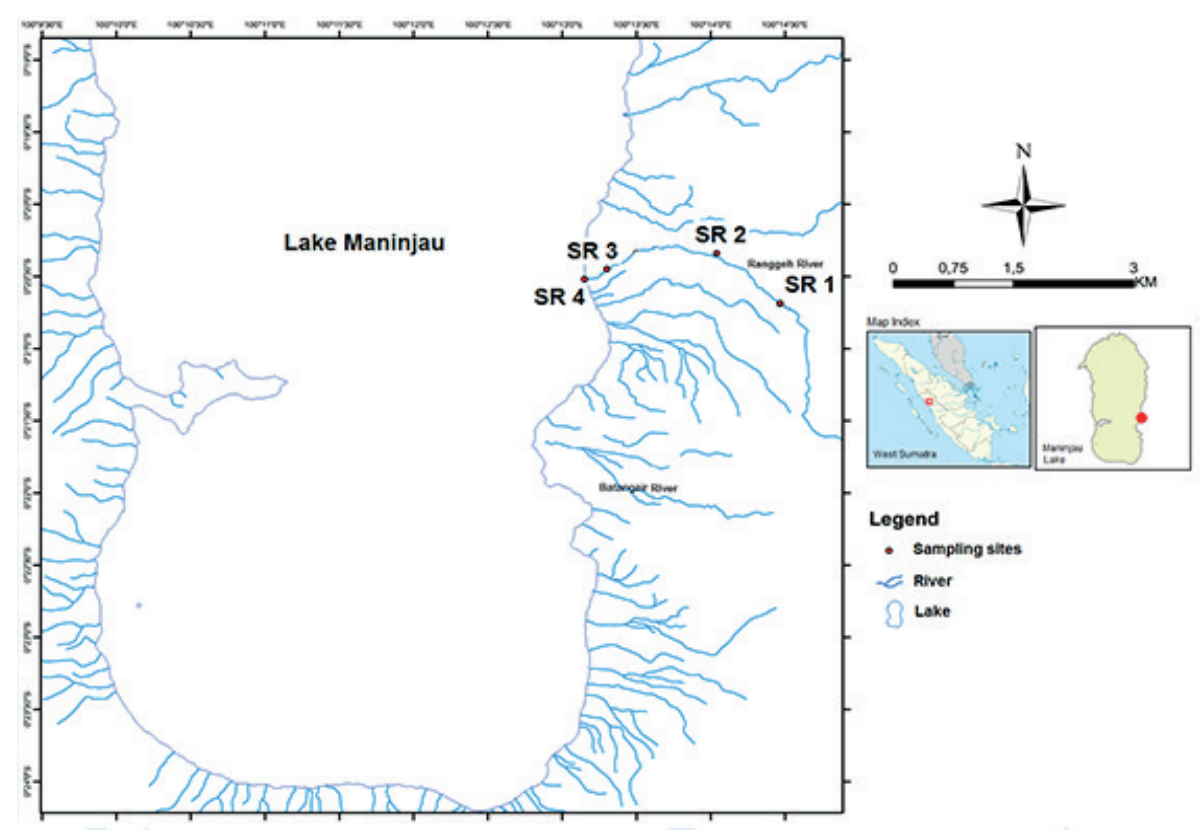

Figure 1. The map of sampling area di Ranggeh River 
Table 1. Description of habitat conditions for sampling sites on the Ranggeh River

\begin{tabular}{|c|c|c|c|}
\hline No & Station & Coordinates point & River Characteristics \\
\hline 1 & SR1 & $\begin{array}{l}\text { S: } 0^{0} 20^{\prime} 34,0^{\prime \prime} \\
\text { E: } 100^{\circ} 14^{\prime} 19^{\prime \prime}\end{array}$ & $\begin{array}{l}\text { The headwaters of the Ranggeh River is at an altitude of } 810 \mathrm{~m} \text { above sea level } \\
\text { (asl). The river was } \pm 50 \mathrm{~cm} \text { deep and } 80 \mathrm{~cm} \text { wide. On the right side was a stretch } \\
\text { of rice fields, and the left side laid a forest. This site became a source of water for } \\
\text { irrigation of rice fields downstream. The water discharge was relatively large, with } \\
\text { an average of } 0.18 \mathrm{~m}^{3} / \text { second. Large and small rocks dominated the substrates. } \\
\text { Physically, the water was relatively clear, which reflected the minimal disturbance } \\
\text { by agriculture. }\end{array}$ \\
\hline 2 & SR2 & $\begin{array}{l}\text { S: } 0^{0} 20^{\prime} 33,1^{\prime \prime} \\
\text { E: } 100^{\circ} 14^{\prime} 15^{\prime \prime}\end{array}$ & $\begin{array}{l}\text { The second site is at } \pm 500 \text { meters away from SR } 1 \text { with an altitude of } 625 \mathrm{~m} \text { above } \\
\text { sea level. The water discharge was quite large, about } 0.04 \mathrm{~m}^{3} / \mathrm{second} \text { with a } \\
\text { depth of } \pm 30 \mathrm{~cm} \text { and } \pm 80 \mathrm{~cm} \text { in width. Bed substrate consisted of large and small } \\
\text { stones, and a rice field was laid both in the right and left in. The water was cloudy } \\
\text { brown, which came from agricultural activities. }\end{array}$ \\
\hline 3 & SR3 & $\begin{array}{l}\text { S; } 0^{0} 20 ' 50,1^{\prime \prime} \\
\text { E:100'13"24,1" }\end{array}$ & $\begin{array}{l}\text { The third is } 5,300 \text { meters from the reference site with an altitude of } 450 \mathrm{~m} \text { above } \\
\text { sea level. The average river water discharge at this station was about } 0.03 \mathrm{~m}^{3} / \\
\text { second with a depth was about } \pm 20 \mathrm{~cm} \text { and the width was } \pm 50 \mathrm{~cm} \text {. On this site, } \\
\text { there was a small spring. Both on the right and left side of the river were rice fields } \\
\text { and a few residential areas. The river was only } \pm 1.2 \text { meters in width. The riverbed } \\
\text { mostly was fine sand. The slope was vulnerable to landslides so that in July and } \\
\text { August } 2020, \text { SR } 3 \text { and SR } 4 \text { gabion wires were installed to reinforce the river } \\
\text { cliffs. In that month, the middle of the river has been planted with gravel stones } \\
\text { to increase the habitat's heterogeneity. The water looks relatively clear and the } \\
\text { bottom substrate was dominated by fine sand in some areas. The landslide marks } \\
\text { were visible. }\end{array}$ \\
\hline 5 & SR5. & $\begin{array}{l}\text { S: } 0^{0} 20^{\prime \prime} 51,3 " \\
\text { E: } 100^{\circ} 13^{\prime \prime} 17,1^{\prime \prime}\end{array}$ & $\begin{array}{l}\text { The fourth location is approximately } 5,700 \text { meters from the reference site with an } \\
\text { altitude of } 449 \mathrm{~m} \text { above sea level. This was the mouth of a river which is directly } \\
\text { adjacent to Lake Maninjau. The average river water discharge was around } 0.04 \\
\mathrm{~m}^{3} / \text { second with a depth of } \pm 20 \mathrm{~cm} \text { and a width of } \pm 50 \mathrm{~cm} \text {. Similar to the others } \\
\text { site, there were rice fields both on the side of the river. Landslide marks were } \\
\text { visible on the right and left edges. The river was relatively small and has lots of } \\
\text { sandbars. In July and August, gabion wires were also installed at the river's edge } \\
\text { and gravel stones on the middle side. }\end{array}$ \\
\hline
\end{tabular}

organisms compared to the pools (De Pauw et al., 2006; Klemm et al., 1990). The transect method is applied to retrieve macroinvertebrate benthic organisms in the river, with three times repetition (left side, center, and right side) in each location. The samples were compiled, rinsed with water, and preserved in 96\% of ethanol (Barbour et al., 1996). Each sample was put in a ziplock bag and given a label. An Olympus SZ-61 stereo microscope with up to $80 \mathrm{x}$ in magnification was used to sort macroinvertebrates. The identification to the level of genus referred to Merritt \& Curnmins (2019), Yule \& Sen (2004), and Thorp \& Covich (1991).

\section{Water quality measurement}

Water quality parameters including dissolved oxygen (DO), pH, temperature, conductivity, total dissolved solids (TDS), and turbidity were assessed directly in the field three times in repetition by using the Horiba U-50 Water Quality Checker. The width of the river during the study was relatively small, so that the water sampling for nutrient analysis (TN and TP) was carried out in the middle of the river. TN and TP analysis required specific bottles which were made from HDPE (high-density polyethylene) plastic bottles. These two parameters were analyzed in the Research Center for Limnology LIPI by using a spectrophotometer. TN was analyzed by brucine method, while TP was measured using ammonium molybdate (APHA, 2005). In addition, a small shovel has been used to take sand, which is about $500 \mathrm{~g}$ of from sediment samples. The percentage of sand in the sediment was determined by using the granulometric method. A stratified sieve (pore size of $2 \mathrm{~mm}$ to $0.063 \mathrm{~mm}$ ) was used to sand separation (Gee \& Bauder, 1986). Meanwhile, the stones embedded in the riverbed were evaluated qualitatively at each observation station (Hamid \& Rawi, 2011). Furthermore, the potential risk of disturbance arising from the measured water quality parameters was compared to the guideline of the Republic of Indonesia Government Regulation No 82 of 2001 for class II water quality (for fisheries).

\section{Data analysis}

The degradability of organic pollution status at each station was analyzed by using the minimum water quality index (WQI ${ }_{\text {min }}$ ). The formula for calculating the $\mathrm{WQI}_{\text {min }}$ value, according to Simôes et al. (2008), is as follows: 


$$
W Q I_{\min }=\frac{C D O+C T u r b+C T o t P}{3}
$$

$\mathrm{CDO}$ is the value of the DO parameter after normalization. CTurb is the value of the turbidity parameter after normalization, and CTotP is the value of the total phosphorus parameter after normalization. The normalization of the three parameters above can be seen in Simôes et al., (2008). The criteria for the WQI ${ }_{\text {min }}$ score are as follows (Fullazaky et al., 2010):

- $\mathrm{WQI}_{\min }$ score $>80-100=$ very good

- $\mathrm{WQI}_{\min }$ score $>60-80=$ good

- $\mathrm{WQI}_{\min }$ score $>40-60=$ moderate

- $\mathrm{WQI}_{\min }$ score $>20-40=$ bad

- $\mathrm{WQI}_{\min }$ score 0-20 = very bad

Similarity analysis statistics (ANOSIM) has been used to test the differences of the benthic macroinvertebrates composition and abundance among the stations. The tes was performed by using CAP software version 6.2.4.479 (Pisces Conservation Ltd). Three metrics of biological indices including taxa number of Ephemeroptera Plecoptera and Trichoptera (EPT), percent of affinity model (PMA), and Family Biotic Index (FBI) have been applied to assess the level of disturbance that occured in the Ranggeh River. The criteria on values the number of EPT taxa are as follows (Bode et al., 1991):

- $>10=$ no disturbances,

- $6-10=$ mild disturbances,

- 2-5 = moderate disturbances,

- $0-1=$ severe disturbances

PMA is a measurement of the seven major macroinvertebrate taxa groups (Oligochaeta, Ephemeroptera, Plecoptera, Coleoptera, Trichoptera, Chironomidae, etc.) which reflected disturbances in river ecosystems. PMA calculation and the criteria for these two metrics was referred to Bode et al. (1991). The criteria for PMA are as follows:

- > 64 = excellent / not yet experiencing disturbances,

- $64-50=$ good,

- 49-35 = moderate,

- $<35=$ severe.

The calculation of the Family Biotic Index $(F B I)$ uses the following formula:

$$
F B I=\frac{n_{i} \times T}{N}
$$

where: $n_{i}=$ number of individuals of the ith species, $T=$ tolerance value for each family, $N=$ total abundance of individuals found in the sample.
The tolerance value for each family of benthic macroinvertebrate and the FBI criteria referred to Lenat (1993). Water quality criteria based on the FBI score on organic pollution disturbance are as follows:

- $>7.26=$ very bad,

- $6.51-7.25=$ bad,

- $5.76-6.5$ = quite bad,

- $5.01-5.75=$ moderate,

- $4.26-5=$ good,

- $3.76-4.25=$ very good,

- $0-3.75=$ excellent.

The sensitivity of those three indices above to the water quality parameters were tested with a correlation of Pearson-Product Moment. The test was performed by using STATISTICA software version 10 (Statsoft).

Direct ordination techniques with Canonical Correspondence Analysis (CCA) were applied to observe each environmental variable contribution to the composition of the macroinvertebrate community at each observation station (Ter Braak \& Verdonschot 1995). Species abundance data transformations were performed using square root with a range of 0 to more than $100 \mathrm{indv} / \mathrm{m}^{2}$ (Marchant \& Hehir, 1999, Clarke \& Warwick, 2001). CCA ordination analysis was carried out by using the MVSP version 3.1 software (Covach Ltd.).

\section{RESULTS}

Table 2 illustrates the result of water quality monitoring in Ranggeh River from February to August 2019. Most of the parameters measured still meet the water quality standards of class II except for the turbidity parameter that has passed the threshold. Several water quality parameters (TDS, pH, DO, water temperature, current velocity, sand percentage, and embeddedness percentage) were significantly different $(\mathrm{p}<0.05)$ among the stations. Other parameters such as TN and TP did not show significant differences $(p>0.05)$ within stations.

The status of water quality based on the water quality index (WQI ${ }_{\text {min }}$ ) is illustrated in Table 3. The water quality in SR1 station is categorized as very good, with a mean value about 96.7. Meanwhile, SR2 station has a mean value of 67.8 , which was grouped as moderate. Two last stations, SR3 and SR4 have mean values respectively about 76.7 and 70.6, which means in the good category. 
Table 2. Ranggeh River water quality (mean \pm SD) and significance level $(p=0.05)$. The guidelines are based on the Republic of Indonesia's Government Regulation for water quality class II (fisheries). Description: Dev = deviation

\begin{tabular}{|c|c|c|c|c|c|c|}
\hline \multirow{2}{*}{ Parameters } & \multicolumn{4}{|c|}{ Sampling Sites } & \multirow{2}{*}{ Guideline } & \multirow{2}{*}{ probability } \\
\hline & SR1 & SR2 & SR3 & SR4 & & \\
\hline TDS (mg/l) & $42.2 \pm 4,2$ & $77.1 \pm 3,3$ & $96,05 \pm 34,5$ & $96,85 \pm 37,1$ & 1000 & $p=0.004$ \\
\hline $\mathrm{pH}$ & $7.8 \pm 0.57$ & $7.8 \pm 0.6$ & $7.08 \pm 0.2$ & $7.3 \pm 0.3$ & $6-9$ & $p=0.0319$ \\
\hline $\mathrm{DO}(\mathrm{mg} / \mathrm{l})$ & $8.2 \pm 0.6$ & $7.9 \pm 0.5$ & $6.2 \pm 0.94$ & $6.2 \pm 0.56$ & 6 & $p=0.0002$ \\
\hline Conductivity (mS/cm) & $0.098 \pm 0.03$ & $0.101 \pm 0.03$ & $0.15 \pm 0.02$ & $0.15 \pm 0.05$ & - & $p=0.09$ \\
\hline Turbidity (NTU) & $7,04 \pm 9,44$ & $51,03 \pm 23,9$ & $43,43 \pm 89,1$ & $45,33 \pm 90$ & 5 & $p=0.638$ \\
\hline Temperature $\left({ }^{\circ} \mathrm{C}\right)$ & $21.5 \pm 0.34$ & $23.6 \pm 1.6$ & $27,26 \pm 0,8$ & $27,69 \pm 1,1$ & Dev.3 & $p=0.00001$ \\
\hline Current speed (m/det) & $2,72 \pm 1,38$ & $0,84 \pm 0,49$ & $0,58 \pm 0,41$ & $0,68 \pm 0,45$ & - & $p=0.0003$ \\
\hline $\mathrm{TN}(\mathrm{mg} / \mathrm{l})$ & $0.54 \pm 0.4$ & $0.68 \pm 0.3$ & $0.54 \pm 0.16$ & $0.6 \pm 0.37$ & 10 & $p=0.89$ \\
\hline $\mathrm{TP}(\mathrm{mg} / \mathrm{l})$ & $0.05 \pm 0.05$ & $0.07 \pm 0.05$ & $0.06 \pm 0.02$ & $0.06 \pm 0.03$ & 0.2 & $p=0.939$ \\
\hline$\%$ Sand & $92,2 \pm 0.28$ & $86,7 \pm 3,9$ & $91,67 \pm 0,54$ & $91,6 \pm 0,54$ & - & $p=0.0003$ \\
\hline$\%$ Embeddedness & $20 \pm 1,3$ & $31 \pm 1,3$ & $46 \pm 9,1$ & $52 \pm 9,4$ & - & $p=0.00001$ \\
\hline
\end{tabular}

Table 3. Current status of water quality in Ranggeh River

\begin{tabular}{|c|c|c|c|}
\hline Stations & $\begin{array}{c}\text { Value of WQI } \\
\text { (minimum-maximum) }\end{array}$ & Mean \pm SD & Category \\
\hline SR1 & $83-100$ & $96.7 \pm 6.7$ & Very good \\
\hline SR2 & $57-77$ & $67.8 \pm 8.3$ & Moderate \\
\hline SR3 & $50-90$ & $76.7 \pm 15$ & Good \\
\hline SR4 & $63-80$ & $70.6 \pm 10.2$ & Good \\
\hline
\end{tabular}

Table 4. Results of ANOSIM test on benthic macroinvertebrate communities at each station

\begin{tabular}{|c|c|c|c|}
\hline \multicolumn{2}{|c|}{ Multiple tests between Sites } & Sample statistic $(r)$ & Significance \\
\hline SR1 & SR2 & 0.709 & $\mathrm{p}=0.0011$ \\
\hline SR1 & SR3 & 0.99 & $\mathrm{p}=0.0011$ \\
\hline SR1 & SR4 & 0.86 & $\mathrm{P}=0.0011$ \\
\hline SR2 & SR3 & 0.95 & $\mathrm{P}=0.0011$ \\
\hline SR2 & SR4 & 0.71 & $\mathrm{P}=0.0011$ \\
\hline SR3 & SR4 & 0.31 & $\mathrm{P}=0.16$ \\
\hline
\end{tabular}

Table 4 shows the analysis of multiple tests with ANOSIM on the composition and abundance of benthic macroinvertebrates in Ranggeh River. There is a significant difference in the benthic macroinvertebrates community between observation stations $(\mathrm{p}<0.05)$. However, SR3 and SR4 did not show a significant difference $(\mathrm{p}>0.05)$.

Several biological indices in reflecting the level of disturbance in Ranggeh River level can be observed in Figure 2. The whisker-plot graph shows that the PMA and EPT metrics have declined heading to the downstream. On the other hand, the FBI metric tends to increase to downstream, which indicates that the water quality is worse. In the whisker-plot graphs of EPT and FBI metrics, there was relatively little overlap between stations SR1, SR2, and SR3. At Station
SR3 and SR4, a lot of overlap can be seen in the graphs, which shows that they are not significantly different. Meanwhile, the biological index PMA was relatively less sensitive in reflecting the disturbances at stations SR 2, SR3, and SR4, which is shown by the overlap of many whisker-plot graphs. Criteria of the Ranggeh River with the three biological indices above can be seen in Table 5. The EPT metric in SR 1 has a mean value of 12 , with the category not yet experiencing interference. Stations SR 2 to SR 4 are categorized as mild to moderate interference. Moreover, the PMA index at stations SR 2 and SR 4 is in the moderate category, but for SR 3 has experienced severe problems. While, the FBI metric in SR1 shows excellent quality with a mean value of 3.6. At station SR 2, the 

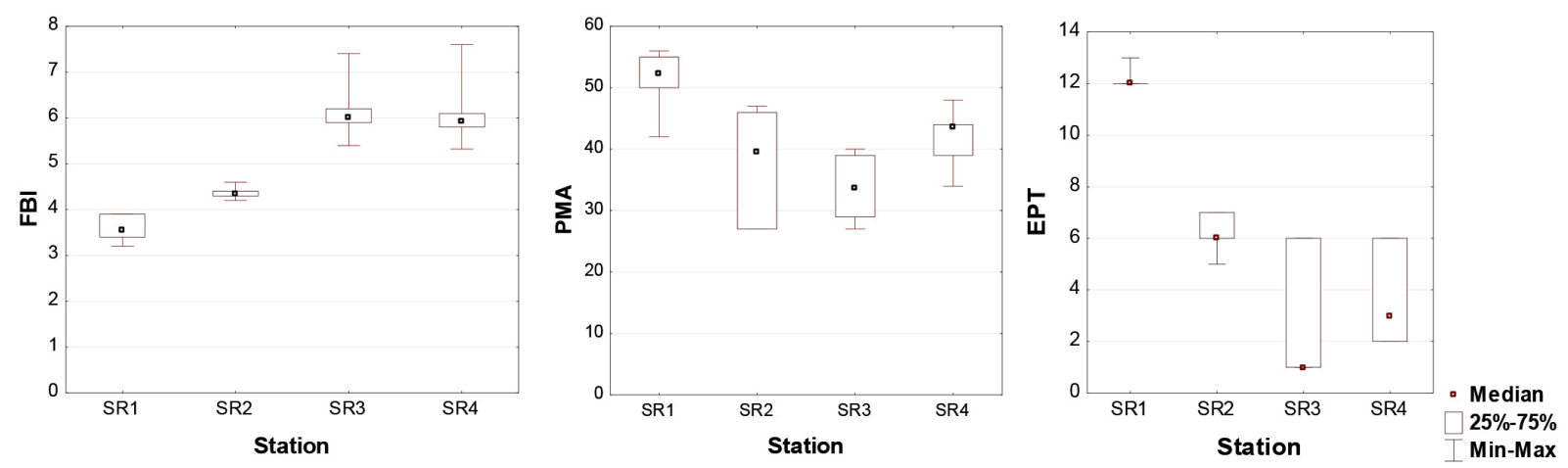

Figure 2. Whisker-plot graph of the biological index values of EPT, PMA, and FBI at each station

Table 5. Score value (mean \pm SD) and biological index criteria for EPT, PMA, and FBI in Ranggeh River

\begin{tabular}{|c|c|c|c|c|c|c|}
\hline Station & EPT & Criteria & PMA & Criteria & FBI & Criteria \\
\hline SR1 & $12 \pm 0.4$ & no disturbances & $53 \pm 2.3$ & good & $3.6 \pm 0.3$ & very good \\
\hline SR2 & $6 \pm 0.7$ & mild disturbances & $38 \pm 8.9$ & moderate & $4.4 \pm 0.1$ & good \\
\hline SR3 & $3 \pm 2.5$ & $\begin{array}{c}\text { moderate } \\
\text { disturbances }\end{array}$ & $34 \pm 4.2$ & moderate & $6.2 \pm 0.6$ & quite bad \\
\hline SR4 & $4 \pm 1.8$ & $\begin{array}{c}\text { moderate } \\
\text { disturbances }\end{array}$ & $42 \pm 4.8$ & moderate & $6.1 \pm 0.7$ & quite bad \\
\hline
\end{tabular}

quality decreased to be good with a mean value of 4.4. Station SR 3 and SR 4 have relatively the same water quality, which is entirely wrong with a mean value respectively of 6.1 and 6.2.

The results of the correlation between environmental variables and the biological index is shown in Table 6. The EPT and FBI metrics have a strong correlation $(\mathrm{p}<0.05)$ with the variables of TDS, $\mathrm{DO}$, temperature, current velocity, and embeddedness percentage. Similarly, the PMA metric has a strong correlation with the parameters previously mentioned but does not show any correlation with the current velocity. The EPT biological index was the only one which has a strong correlation with the water quality index $\left(\mathrm{WQI}_{\min }\right)$.

Ordination analysis with CCA on the benthic macroinvertebrate community in Ranggeh River as shown in Table 7 and Figure 3. The cumulative percentage explained from axis one and two is about $71.5 \%$ and the magnitude of the correlation between species and environment on axes one and two are about 0.95 and 0.87 . Meanwhile, Figure 2 shows three stations based on the abundance and benthic composition of macroinvertebrates in each observation station. These groups include groups 1 (SR1), 2 (SR2), and 3 (SR3 and

Table 6. Spearman correlation between environmental variables with biological indices of EPT, PMA, and FBI. Values in bold are significant at the $p=0.05$ level

\begin{tabular}{|l|c|c|c|}
\hline \multicolumn{1}{|c|}{ Parameters } & EPT & PMA & FBI \\
\hline TDS & -0.5 & -0.5 & -0.5 \\
\hline $\mathrm{pH}$ & 0.27 & 0.22 & -0.44 \\
\hline DO $(\mathrm{mg} / \mathrm{l})$ & 0.70 & 0.54 & 0.31 \\
\hline Conductivity & -0.14 & -0.28 & 0.05 \\
\hline Turbidity & -0.09 & -0.12 & 0.81 \\
\hline Temperature & -0.73 & -0.53 & -0.54 \\
\hline Kecepatan arus & 0.5 & 0.3 & 0.06 \\
\hline TN & 0.12 & -0.2 & 0.1 \\
\hline TP & -0.09 & 0.08 & -0.08 \\
\hline$\%$ Sand & 0.22 & 0.23 & 0.91 \\
\hline$\%$ Embeddedness & -0.87 & -0.5 & -0.39 \\
\hline Water Quality Index $\left(\mathrm{WQI}_{\text {min }}\right)$ & 0.5 & 0.33 & \\
\hline
\end{tabular}


Table 7. Ordination results between the benthic macroinvertebrates community and environmental variables using CCA

\begin{tabular}{|l|c|c|c|}
\hline \multicolumn{1}{|c|}{ Specification } & Axis 1 & Axis 2 & Axis 3 \\
\hline Eigenvalues & 0.558 & 0.161 & 0.124 \\
\hline Percentage & 34.428 & 9.915 & 7.633 \\
\hline Cumulative percentage & 34.428 & 44.343 & 51.976 \\
\hline Cumulative constrained percentage & 55.520 & 71.508 & 83.817 \\
\hline Species-environment correlations & 0.950 & 0.872 & 0.762 \\
\hline
\end{tabular}

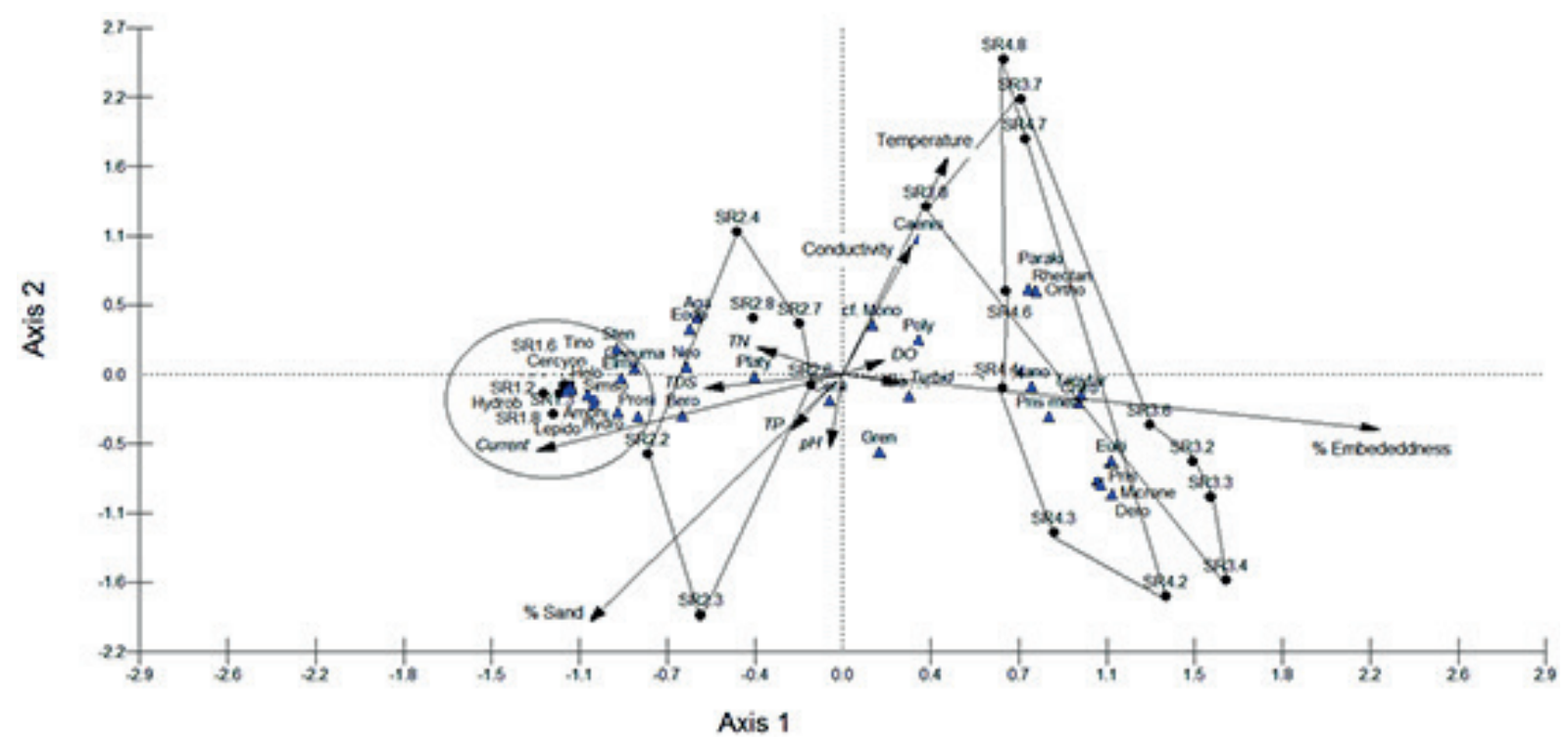

Figure 3. Triplot graph of CCA ordination in benthic macroinvertebrates community in the Ranggeh River. Information: Aga = Agapetus, Amphi $=$ Amphinemura, Bero $=$ Berosus, Cera $=$ Ceratopsyche, Cercyon $=$ Cercyon, Cheuma $=$ Cheumatopsyche, Chiro $=$ Chironomus, Dero $=$ Dero $($ dero $)$ digitata , Elmo $=$ Elmomorphus, Eoo= Eoophyla, Euki $=$ Eukiefferiella, Gren $=$ Greniera, Helo $=$ Helophorus, Hydro $=$ Hydropsyche, Hydrob $=$ Hydrobasileus, Lepido $=$ Lepidostoma , Microne $=$ Micronecta, Mono $=$ Monopelopia, $\mathrm{Neo}=$ Neoperla, Ortho $=$ Orthocladius, Paraki $=$ Parakiefferiella, Platy $=$ Platybaetis, Poly $=$ Polypedilum, Pris $=$ Pristina synclites, Pris men $=$ Pristina menoni, Pros $=$ Prosimulium, Rheotan= Rheotanytarsus, Simso $=$ Simsonia, Sten $=$ Stenelmis, Tanytar $=$ Tanytarsus, Tino $=$ Tinodes.

4). As seen, Groups 1 and 2, on the left side of the triplot graph, covers the order of Plecoptera (Amphinemura, Neoperla), Trichoptera (Hydropsyche, Tinodes, Lepidostoma, Cheumatopsyche), Coleoptera (Berosus, Stenelmis, Simsonia, Cercyon), Diptera (Prosimulium), and Odonata (Hydrobasileus). Those groups tend to be characterized by current velocity, a relatively high sand percentage, and a relatively low embeddedness percentage. In the contrast, SR 3 and SR 4 are dominated by Diptera Chironomidae larvae from subfamily of Orthocladiinae (Parakiefferiella, Orthocladius, Eukiefferiella), Tanypodinae (Monopelopia), Chironomidae (Tanytarsus, Chironomus, and Rheotanytarsus), Hemiptera and Oligochaeta worms (Pristina synclites, Pristina Menoni, Dero (dero) digitata). The groups tend to be characterized by high embeddedness percentage variables, low current velocity, and sand percentage. Ephemeroptera Caenis sp. Was more characterized by high temperature and conductivity. Other parameters such as DO, TN, TP, TDS, and $\mathrm{pH}$ have a little contribution in influencing the benthic macroinvertebrate community in Ranggeh River.

\section{DISCUSSION}

The impact of agricultural and domestic activities such as land clearing and tillage for agriculture around the Ranggeh River has generally led to increased water quality parameters. Egler et al. (2012) mention the impact of agricultural activities on rivers, including changes in riparian vegetation and river morphology, nutrient and organic enrichment, and pesticide contamination. 
The relatively open riparian vegetation conditions allow run-off water to enter the drainage system to the river. The turbidity parameter increased several times over the class II (fishery) Indonesian water quality standard. The increase in the turbidity parameter is influenced by the season when sampling and rice planting. During the rainy season, a lot of soil material is transported by run-off to the river. In February-April 2019, many farmers plow their fields in preparation for planting seeds. Runoff water from rice fields can enter the drainage system, thereby increasing the turbidity value of the Ranggeh River. Quinn et al. (1992) stated that turbidity values above 23 NTU were able to reduce the taxa richness and density of most macroinvertebrate benthic organisms. Judging from the turbidity parameter value, the SR2 to SR4 stations have the potential to disrupt animal life.

The measurement of water quality in the Ranggeh River (Table 2) shows that several physical and chemical variables (TDS, $\mathrm{pH}, \mathrm{DO}$, temperature, current velocity, sand percentage, and embeddedness percentage) have significantly different between stations $(\mathrm{p}<0.05)$. The existence of significant differences in the variables of current velocity, water temperature, and sand percentage was influenced by the differences of geomorphological factors (e.g., altitude). SR1 Station is the upstream part of the river, included in the highlands ( $810 \mathrm{~m}$ asl). This condition can affect other water quality parameters such as water temperature $\left(21.5^{\circ} \mathrm{C}\right)$, dissolved oxygen $(8.2$ $\mathrm{mg} / \mathrm{l})$, and current velocity $(2.72 \mathrm{~m} / \mathrm{s})$. Many rock substrates in the riverbed and the high current velocity in SR1 resulted in water turbulence, so that the level of dissolved oxygen (DO) was inclined. Gradually with the decreasing of altitude and the impact of clearing agricultural land, and settlements, it is possible to increase several parameters such as TN, TP, turbidity, TDS, and conductivity (Sagasta et al., 2017). DO level may tend to be lower when the input of degradable organic matter such as manure has been received (Egler et al., 2012).

Water quality index $\left(\mathrm{WQI}_{\mathrm{min}}\right)$ indicates that the water quality in SR1 was in the very good category, SR3 and SR4 were in good categories, and SR2 was in the moderate disturbance category. $\mathrm{WQI}_{\min }$ was based on three parameters including: DO, Turbidity, and TP. In fact, SR2 station is densely populated with agricultural activities, which directly affected the turbidity and TP values. The water quality index of SR2 was lower than SR3 and SR4; moreover, an inlet from a small spring in SR3 might increase the value. Meanwhile, SR3 and SR4 altitude starts to slope which decreases the current velocity. This precipitated the suspended sediment particles and the percentage of embeddedness at the two stations tends to be high compared to the previous station.

ANOSIM test results in Figure 1 shows that the impact of anthropogenic activities in Ranggeh River caused significant changes in the abundance and composition of macroinvertebrates. It could affect the value of the biological index (EPT, PMA, and FBI). EPT and FBI metrics were relatively superior to PMA in reflecting the ecological disturbances that occur in Ranggeh River. EPT metric shows more stable and sensitive than taxa richness in disturbances detection in the lotic ecosystem (Brabec et al., 2004). Commonly, EPT values $>10$ indicates the river quality met water quality criteria on I and II of raw water for drinking and fisheries purposes (Hamid \& Rawi, 2011). In general, EPT taxa are lithophilous (associated with rock substrates) where live in the eucrenal and epirhitral parts with clean or less polluted waters (Stoyanova et al., 2014). Molokwu et al. (2014) mentioned that the larvae of the Ephemeroptera (Canidae), Plecoptera (Perlidae), and Trichoptera (Hydropsychidae) have a preference to associated with rock substrates. The high increase of rocks embedded in the sediment (embeddedness percentage) as in SR 3 and SR 4 , might have disrupted these organisms and decreased the number of EPT taxa. Hamid \& Rawi (2011) stated that Malaysia's Terri River's EPT value tends to be low when its embeddedness reaches by about $50-75 \%$.

In this study, all the biological indices seem to have a negative correlation with the percentage of embeddedness. Most of the bottom substrate has been covered by fine and relatively homogeneous sediments at SR 3 and SR 4. This caused the low number of macroinvertebrate taxa which were categorized as sensitive to disturbance. The heterogeneity of the substrates has been identified as a determining factor for the benthic macroinvertebrate community structure. More space and available surface area of the substrate will increase the taxa and abundance of benthic macroinvertebrate (Allen \& Vaughn, 2010; Shostell \& Williams, 2007). In the end, the complexity of the habitat structure will more support the diversity of the macroinvertebrates community (McGoff et al., 2013). 
The Family Biotic Index further developed the Hilsenhoff biotic index (HBI) (Lenat, 1993). The FBI metric combined tolerance values at the family level and the abundance of macroinvertebrate against organic pollution in the rivers. The descreased of intolerant organisms such as EPT will directly increase the FBI score. A high score on the biotic index indicates that many species are tolerant of temperature fluctuations, fine sediment input, and organic enrichment (Cole, 2013; Lenat, 1993). PMA metrics are mainly based on the balance of individual abundances of the seven indicator taxa populations (Bode et al., 1991). Commonly, the metric response to the abundance of macroinvertebrates varies with disturbances and makes them less sensitive in detecting changes or disturbances in aquatic ecosystems (Barbour et al., 1996).

Spearman correlation analysis between the biological index and environmental variables shows that EPT was relatively sensitive in detecting water quality changes in the Ranggeh river, which was followed by the FBI and PMA. The increase of TN and TP parameters in the Ranggeh River due to anthropogenic activities did not negatively affect this biological index. It might be closely related to these burdens of parameters, which probably cause relatively less harm to the macroinvertebrate community. Sultana et al. (2019) mentioned that TN and TP concentrations in the Torrens River and Australian Onkaparinga $\mathrm{TN}$ was about $4,450 \mathrm{mg} / \mathrm{L}$ and $5,6 \mathrm{mg} / \mathrm{L}$, while $\mathrm{TP}$ was about $0.87 \mathrm{mg} / \mathrm{L}$ and $0.56 \mathrm{mg} / \mathrm{L}$ which able to support taxa richness of macroinvertebrate were 72 and 74 . TN and TP concentrations in Ranggeh River have relatively met the class II of water quality standards for fisheries purposes, which TP was about $10 \mathrm{mg} / \mathrm{L}$ and TN was about $0.2 \mathrm{mg} / \mathrm{L}$ (Government Regulation of the Republic of Indonesia, 2001). Barlow-Busch et al. (2006) stated that TP enrichment by anthropogenic activities in the waters $>30 \mu \mathrm{g} \mathrm{P} / \mathrm{L}$ could significantly increase benthic algae biomass in the rivers. Based on Barlow-Busch et al. (2006), the mean concentration of TN $(0.54-0.68 \mathrm{mg} / \mathrm{L})$ and TP (0.05-0.07) in Ranggeh River allow to support the growth of algal biomass as natural food for benthic macroinvertebrates. Meanwhile, the water quality index $\left(\mathrm{WQI}_{\min }\right.$ ) shows that changes in the water quality (a combination of DO, turbidity, and TP) in Ranggeh river contribute to changes in the EPT taxa. Generally, sensitive EPT metrics are used to detect disturbances in the river due to sedimentation, pollution, or disasters (such as forest fires and oil spills). Therefore, Ephemeroptera, Plecoptera, and Trichoptera taxa are categorized as intolerant of pollution and suitable for water indicators (Hamid \& Rawi, 2011).

Ordination with CCA (Figure 3), shows that the changes of bottom substrate (embeddedness percentage) due to sedimentation was mainly impacting the macroinvertebrates community structures rather than organic enrichment (DO, TN, TP) factors. Sensitive taxa such as Plecoptera ( $\mathrm{Am}$ phinemura, Neoperla), Trichoptera (Hydropsyche, Tinodes, Lepidostoma), Coleoptera (Berosus, Stenelmis), Diptera Simuliidae (Prosimulium), and Odonata (Hydrobasileus) have a preference inhabit in fast-flowing water with minimal disturbance of sedimentation. Plecoptera and Trichoptera larvae are grouped as sensitive to water quality changes, so they are suitable for river health indicators. Some members of these two taxa live in the cold water with fast current and pebbles and cobbles in the bottom of the substrate (Gooderham \& Tsyrlin, 2003). Hydrophilidae beetle larvae (such as Berosus) usually inhabit stagnant waters with slow-current, dense aquatic plants (Mesaros \& Novakovic, 2015), and less sensitive to pollution (Gooderham \& Tsyrlin, 2003). Meanwhile, Elmids beetles (such as Stenelmis) are commonly found in the upper area of rivers with the high level of dissolved oxygen and populated with submerged wood or rock surfaces. Therefore, they are relatively sensitive to organic pollution. Simulid and Odonata larvae have been categorized as intermediate organisms that are slightly sensitive to water quality degradation (Patang et al., 2018; Gooderham \& Tsyrlin, 2003).

Sites that have been affected by agricultural activity generally have a low number of taxa and tolerant macroinvertebrates groups (Hepp et al., 2010). The larvae of Ephemeroptera Canidae generally have a low tolerance for pollution. However, some other types of Canidae are facultative to domestic waste pollution and able to adapt to cloudy water conditions (Alhejoj et al., 2014). On the other hand, the Diptera Chironomidae larvae and Oligochaeta worms prefered fine substrates and enrichment of organic material (Gooderham \& Tsyrlin, 2003). Arimoro \& Ikomi (2008) mentioned that Oligochaeta worms and Diptera Chironomid larvae are relatively tolerant of high organic matter and nutrients and leave no macroinvertebrate species to survive. Pristina sp. and Dero (aulophorus) lodeni prefered living in fine sandy habitats with a high dissolved oxygen 
content (Cesar \& Henry, 2017). However, Dero sp. and Tubificinae immature are worms that generally live in waters containing high organic matter (Martin et al., 2008).

Chironomid larvae including subfamilies of Chironominae, Tanypodinae, and Orthocladiinae are widely distributed worldwide (Epler, 2001; Armitage et al., 1995). Chironomidae distribution well-adapted easily, so that make them welldistributed in almost all types of water bodies (lotic, lentic, and marine) (Zorina et al., 2014; Wardiatno \& Krisanti, 2013; Epler, 2001; Armitage et al., 1995). Chironomidae larvae have a wide tolerance range in pollution from sensitive to tolerant (Moller Pillot, 2013b: Lindegaard, 1995). In general, the present of chironomid larvae is associated with the preference for fine substrates and enrichment of organic matter (Patang et al., 2018). The sub-families Orthocladiinae and Diamesinae usually live in the upstream part of the river, while Tanypodinae and Chironominae commonly inhabit in the downstream (Lindegaard, 1995). Parakiefferiella, Orthocladius, and Eukiefferiella usually live on the rock surface, sand, or organic matter in rivers. Orthocladius has been known to be slightly tolerant of organic pollution, whereas Eukiefferiella prefers habitats with high oxygen content and high flow rates (Moller Pillot, 2013a). Meanwhile, Monopelopia usually lives on the surface of aquatic plants and tends to be resistant to low levels of dissolved oxygen (Vallneduuk \& Moller Pillot, 2013b). Chironomus and Rheotanytarsus inhabit the tubes on mud which are rich in organic matter, sand surfaces, and rocks (Moller Pillot, 2013b). Chironomus sp. relatively resistant to organic and inorganic pollution with the low dissolved oxygen (Al-Shami et al., 2010).

\section{CONCLUSION}

It can be concluded that the influence of agricultural activities and the settlements in Ranggeh River has changed the macroinvertebrate community structure. EPT metrics are relatively more sensitive in reflecting the ecological disturbances in the Ranggeh River which followed by the FBI and PMA. In addition, taxa of Plecoptera (Amphinemura, Neoperla), Trichoptera (Hydropsyche, Tinodes, Lepidostoma), Coleoptera (Berosus, Stenelmis), Diptera Simuliidae (Prosimulium), and Odonata (Hydrobasileus) in the
Ranggeh River are more characterized by embeddedness percentage rather than organic matter enrichment (TN and TP).

\section{Acknowledgments}

This research was funded by the Government of the Republic of Indonesia's Budget Implementation List (DIPA) project for the 2019 fiscal year number: DIPA-079.01.2.418535/ 2019 concerning Lake Health Technology to Support Fishery Cultivation and Tourism in Lake Maninjau. The author would like to thank Laela Sari, who has helped a lot in the sorting of benthic macroinvertebrate organisms. The author also thanks Aan Dianto for making a map of Maninjau Lake and all those who contributed to this research's smooth running.

\section{REFERENCES}

1. Alhejoj I., E. Salameh, K. Bandel. 2014. Mayflies (Order Ephemeroptera): An Effective Indicator of Water Bodies Conditions in Jordan, International Journal of Scientific Research in Environmental Sciences 2(10): 346-354. http://dx.doi.org/10.12983/ IJSRES-2014-p0346-03xx.

2. Allen D.C., C.C. Vaughn. 2010. Complex hydraulic and substrate variables limit freshwater mussel species richness and abundance. $J N \mathrm{Am} \mathrm{Benthol} \mathrm{Soc}$ 29: 383-394.

3. Al-Shami S.A, C.S. Md Rawi, A.H. Ahmad, S.A. Mohd Nor. 2010. Distribution of Chironomidae (Insecta: Diptera) in polluted rivers of the Juru River Basin, Penang, Malaysia. Journal of Environmental Sciences 22(11) 1718-1727.

4. APHA. 2005. Standard Methods for The Examination of Water and Waste Water. New York: American Public Health Association, American Water Work Association, and Water Environmental Federation Inc., in Eaton AD, Clesceri LS, Franson MAH, Rice EW, Greenberg AE (eds). Volume 5. 1220 pp.

5. Arimoto F.O., R.B. Ikomi. 2008. The response of macroinvertebrate communities to abattoir wastes and other anthropogenic activities in a municipal stream in the Niger Delta, Nigeria. The Environmentalist 28: 85-98.

6. Armitage P.D., P. Cranston, L.C.V. Pinder. 1995. The Chironomidae: Biology and Ecology of nonbiting Midges. Springer. UK.106 pp.

7. Barbour M.T., J. Gerritsen, B.D. Snyder, J.B. Stribling. 1999. Rapid Bioassessment Protocols For Use In Streams And Wadeable Rivers: Periphyton, Benthic Macroinvertebrates, And Fish. Second Edition. EPA 841-B-99-002, US-EPA. Office of Water Washington DC. 
8. Barbour M.T., J. Gerritsen, G.E. Griffith, R. Frydenborg, E. McCarron, J.S. White, M.L. Bastian. 1996. A framework for biological criteria for Florida streams using benthic macroinvertebrates. J. N. Am. Benthol. Soc.15(2):185-211.

9. Barlow-Busch L., H.M. Baulch, W.D. Taylor. 2006. Phosphate uptake by seston and epilithon in the Grand River, southern Ontario. Aquatic Sciences 68 (2):181-192.

10. Basset A., F. Sangiorgio, M. Pinna. 2004. Monitoring with benthic macroinvertebrates: advantages and disadvantages of body size descriptors. Aquatic Conserv: Mar. Freshw. Ecosyst.14: 43-58.

11. Besacier-Monbertrand A.L., A. Paillexa, B.E. Castella. 2014. Short-Term Impacts of Lateral Hydrological Connectivity Restoration On Aquatic Macroinvertebrates. River Res. Applic.30: 557-570.

12. Brabec K., S. Zahradkova, D. Nemejcova, J. Paril, P. Kokeš, J. Jarkovsk. 2004. Assessment of organic pollution effect considering differences between lotic and lentic stream habitats. Hydrobiologia 516: 331-346.

13. Bode RW, M.A. Novak, L.E. Abele. 1991. Methods for rapid biological assessment of stream, NYS Dept. of Environmental Conservation. Albany. New York. pp. 57.

14. Cesar D.A.S., R. Henry. 2017. Is similar the distribution of Chironomidae (Diptera) and Oligochaeta (Annelida, Clitellata) in a river and a lateral fluvial area?, Acta Limnologica Brasiliensia 29 (e6).http:// dx.doi.org/10.1590/S2179-975X1217.

15. Clarke K.R, R.M. Warwick. 2001. Change Marine Communities: an approach to statistical analysis and interpretation. 2nd Edition. PRIMER-E. Plymouth.

16. Cole M. 2013. Lower Clackamas River Basin Macroinvertebrate Monitoring Plan. http:/www.clackamasproviders.org/images/stories/13-626_FINAL_ Clack_Mon_Plan_6-17-13.pdf Access: Feb, 2021.

17. De Pauw N, W. Gabriels, P.L.M. Goethals. 2006. River Monitoring and Assessment Methods Based on Macroinvertebrates, Biological Monitoring of Rivers: Applications and Perspectives. Edited by: G. Ziglio, M. Siligardi, and G. Flaim. John Wiley \& Sons.

18. Duan X.H., Z.Y.Wang, M.Z. Xu. 2011. Effects of fluvial processes and human activities on stream macroinvertebrates. International Journal of Sediment Research 26: 416-430.

19. Egler M, D.F. Buss, J.C. Moreira, D.F. Baptista. 2012. The influence of agricultural land-use and pesticides on benthic macroinvertebrate assemblages in an agricultural river basin in southeast Brazil. Braz. J. Biol.72(3): 437-443.

20. Epler J.H. 2001. Identification Manual For The Larval Chironomidae (Diptera) Of North And South Carolina, EPA Region 4 and Human Health And Ecological Criteria Division. North Carolina Department of Environment and Natural Resources
Division of Water Quality. $526 \mathrm{pp}$

21. Fullazaky M.A., T.W. Seong, M.I.M. Masirin. 2010. Assessment of Water Quality Status for The Selangor River in Malaysia. Water Air Soil Pollut 205: 63-77.

22. Gooderham J, E.Tsyrlin. 2003. The Waterbug Book: A guide to the freshwater macroinvertebrates of temperate Australia. CSIRO publishing. Collingwood, Australia. 232pp.

23. Hamid SA., C.S. Rawi. 2011. Influence of substrate embeddedness and Canopy Cover on The Distribution of Ephemeroptera, Plecoptera, and Trichoptera (EPT) in Tropical Rivers, Aquatic Insects: International Journal of Freshwater Entomology 33(4): 281-292.

24. Hepp L, M.S. Biasi, R. Restello. 2010. Effects of agricultural and urban impacts on macroinvertebrates assemblages in streams (the Rio Grande do Sul, Brazil). Zoologia 27(1):106-113.

25. Kenney MA., A.E. Sutton-Grier, R.F. Smith, S.E. Gresens. 2009, Benthic macroinvertebrates as indicators of water quality: The intersection of science and policy, Terrestrial Arthropod Reviews 2: 99-128.

26. Klemm D.J., P.A. Lewis, F. Fulk, J.M. Lazorchak. 1990.Macroinvertebrate Field and Laboratory Methods for Evaluating The Biological Integrity of Surface Waters. US-EPA. Environmental Monitoring and Support Laboratory. Cincinnati. Ohio. WPA-600-4-90-030.

27. Lenat D.R. 1993. A Biotic Index for the Southeastern United States: Derivation and List of Tolerance Values, with Criteria for Assigning Water-Quality Ratings. Journal of the North American Benthological Society 12 (3): 279-290.

28. Lenat D.R., L.A. Smock, D.L. Penrose. 1980. Use of benthic macroinvertebrates as indicators of environmental quality. In Biological Monitoring for Environmental Effects, Worf DL (ed.). D.C. Heath: Lexington, MA; 97-112.

29. Lindegaard C. 1995. Classification of Water Bodies and Pollution, In The Chironomidae: Biology And Ecology of Non-Biting Midges, Edited By P.D. Armitage PS. Cranston, Pinder LCV. Chapman \& Hall, 385-404pp.

30. Meehan W., T.O. Prommi. 2015. Diversity and Distribution of Aquatic Insects in Streams of the Mae Klong Watershed, Western Thailand. Psyche: 1-7, http://dx.doi.org/ 10.1155/2015/912451.

31. Marchant R., G. Hehir. 1999. Growth, Production, and Mortality of Two Species of Agapetus (Trichoptera: Glossosomatidae) in The Acheron River, South-east Australia. Freshwater Biology 42: 655-671.

32. Martins R.T., N.N.C. Stephan, R.G. Alves. 2008. Tubificidae (Annelida: Oligochaeta) as an indicator of water quality in an urban stream in southeast Brazil. Acta Limnologica Brasiliensia 20(3), 221-226 
33. McGoff E., J. Aroviita, F. Pilotto, O.Miler. 2013. Assessing the relationship between the Lake Habitat Survey and littoral macroinvertebrate communities in European lakes. Ecol Indic 25: 205-214.

34. Merritt R.W., K.W. Cummins. 2019. An introduction of the aquatic insects of North America, 5 Ed. Kendall Hunt Publishing Company. Dubuque. Iowa. pp. 1498.

35. Mesaros G., B. Novakovic. 2015. Contribution to the Knowledge of the Aquatic Beetle Genus Berosus Leach (Coleoptera: Hydrophilidae) in Serbia. Water Research and Management 5(4): 45-51.

36. Miller S.W., P. Budy, J.C. Schmidt. 2010. Quantifying Macroinvertebrate Responses to In-Stream Habitat Restoration: Applications of Meta-Analysis to River Restoration. Restoration Ecology 18(1): 8-19.

37. Molokwu N.D, G. Pedro, T. Bradshaw, A. Blake, C. Hennessey, E. Merten. 2014. Effects of substrate on the benthic macroinvertebrate community: an experimental approach. Ecological Engineering 73: 109-114.

38. Moller Pillot H.K.M. 2013a. Chironomidae Larvae of the Netherlands and Adjacent Lowlands:

39. Biology and Ecology of the Aquatic Orthocladiinae. KNNV Publishing. Zeist. The Netherlands. 312 pp.

40. Moller Pillot H.K.M. 2013b. Chironomidae Larvae of the Netherlands and Adjacent Lowlands:

41. Biology and Ecology of the Chironomini. KNNV Publishing. Zeist. The Netherlands. 270 pp.

42. Neisse L, P. Tishehzan, M. Albaji. 2019. Chemical assessment of surface water quality in upstream and downstream of Jare Dam, Khuzestan, Iran.Environmental Earth Sciences 78:83-94. https://doi. org/10.1007/s12665-019-8082-X

43. Patang F, A. Soegianto, S. Hariyanto. 2018. Benthic Macroinvertebrates Diversity as Bioindicator of Water Quality of Some Rivers in East Kalimantan, Indonesia, International Journal of Ecology, https:// doi.org/10.1155/2018/5129421

44. Peraturan Pemerintah RI No 82. 2001. Pengelolaan Kualitas Air dan Pengendalian Pencemaran Air, Republik Indonesia.

45. Quinn J.M., R.J. Davies-Colley, C.W. Hickey, Vickers M.L., Ryan P.A. 1992. Effects of Clay Discharges on Streams. 2. Benthic invertebrates. Hydrobiologia 248; 235-247.

46. Rosenberg D.M, V.H. Resh. 1993. Introduction to freshwater biomonitoring and benthic macroinvertebrates. InFreshwater Biomonitoring and Benthic Macroinvertebrates, Rosenberg DM, Resh VH (eds). Chapman and Hall: New York; 1-9.

47. Sagasta J.M., M.S. Zadeh, H. Turral. 2017. Water pollution from agriculture: a global review. FAO and IWMI. Rome. 29 pp

48. Saraswati S.P., M.V. Ardion, Y.H. Widodo, S. Hadisusanto. 2019. Water Quality Index Performance for
River Pollution Control Based on Better Ecological Point of View (A Case Study in Code, Winongo, Gadjah Wong Streams). Journal of the Civil Engineering Forum 5 (1):47-55.

49. Simôes S.D., S. Moreira, A.B. Bisinori, M.C. Gimenez, J.M.S. Yabe. 2008. Water Quality Index as a Simple Indicator of Aquaculture Effects on Aquatic Bodies. Ecological indicator 8:476-484.

50. Sudarso J., Imroatushshoolikhah, A. Ibrahim, S. Aisyah, L.Sari. 2020. Evaluasi Rehabilitasi Riparian Sungai Ranggeh dengan Menggunakan Indikator Komunitas Makrozoobenthos. Oseanologi dan Limnologi di Indonesia 5(2): 105-119

51. Shortell J.M., B.S. Williams. 2007. Habitat complexity as a determinate of benthic macroinvertebrate community structure in cypress tree reservoirs. Hydrobiologia 575: 389-399

52. Stoyanova T., Y.Vidinova, I. Yaneva, V. Tyufekchieva, D. Parvanov, I. Traykov, V.Bogoev. 2014. Ephemeroptera, Plecoptera, and Trichoptera as Indicators for Ecological Quality of the Luda Reka River, Southwest Bulgaria, Acta Zool. Bul. 66 (2): 255-260.

53. Sultana J., F. Recknagel, J. Tibby, S. Maxwell. 2019. Comparison of water quality thresholds for macroinvertebrates in two Mediterranean catchments quantified by the inferential techniques TITAN and HEA. Ecological Indicators 101: 867-877.

54. Ter Braak C.J.F., P.F.M. Verdonschot. 1995. Canonical Correspondence Analysis and Related Multivariate Methods in Aquatic Ecology. Aquatic Science 57(3): 255-288.

55. Thorp J.H., A.P. Covich. 1991. Ecology and classification of North American freshwater invertebrates. Academic Press. Inc. New York.

56. Vallneduuk H.J., H.K.M. Moller Pillot. 2013. Chironomidae Larvae of the Netherlands and Adjacent Lowlands: General ecology and Tanypodinae, KNNV Publishing, Zeist. The Netherlands, 144pp.

57. Watts J. 2010. Chinese farms cause more pollution than factories, says official survey [available on the internet at http://www.guardian.co.uk/environment $/ 2010 / \mathrm{feb} / 09 /$ china-farmspollution]. Accessed Jun 20, 2012.

58. Xu M., Z. Wang, X. Duan 2014. Effects of pollution on macroinvertebrates and water quality bioassessment. Hydrobiologia 729: 247-259. https:// doi.org/10.1007/ s10750-013-1504-y.

59. Yule C.M., Y.H. Sen. 2004. Freshwater Invertebrates of The Malaysian Region. Academy Science. Malaysia, $861 \mathrm{pp}$.

60. Zorina O.V., A.G. Orel, I.I. Istomina, Kiknadze, T.D. Zinchenko, L.V. Golovatyuk. 2014. Redescription of larva, pupa, and imago of male Chironomus (Chironomus) salinarius Kieffer from the saline rivers of the Lake Elton Basin (Russia), its karyotype, and ecology. Zootaxa 3841 (4): 528-550. 